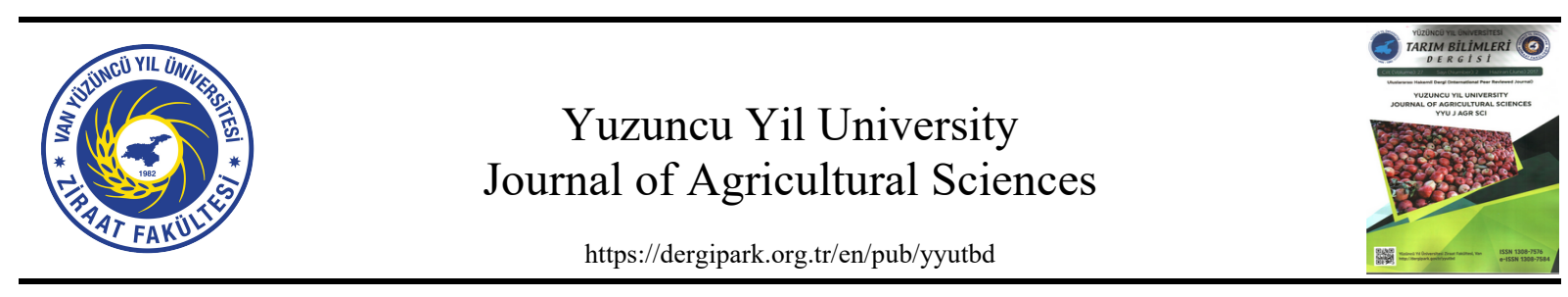

Araştırma Makalesi (Research Article)

\title{
Evaluation of Outdoor Ornamental Plants from the Viewpoint of Urban Biodiversity and Cultural Change in Terrestrial Climate: The Case of Nigde City
}

\author{
Gülden SANDAL ERZURUMLU ${ }^{* 1}$, Dursun Yenal ERZURUMLU ${ }^{2}$ \\ ${ }^{1}$ Niğde Ömer Halisdemir Üniversitesi, Mimarlık Fakültesi, Peyzaj Mimarlığı Bölümü, 51240, Niğde, Türkiye \\ ${ }^{2}$ Niğde Ömer Halisdemir Üniversitesi, Ayhan Şahenk Tarım Bilimleri Uygulama, 51240, Niğde, Türkiye \\ ${ }^{1}$ https://orcid.org/0000-0001-9664-2902 ${ }^{2}$ https://orcid.org/0000-0001-7773-2101 \\ *Corresponding Author: e-posta: gpeyzaj@gmail.com
}

\begin{abstract}
Article Info
Received: 13.01 .2021

Accepted: 13.09.2021

Keywords

Biodiversity,

Home gardens,

Landscape,

Plant species,

Urban Plants.
\end{abstract}

Online Published: 15.12 .2021

DOI: $10.29133 /$ yyutbd.860641

\begin{abstract}
Plant species used in urban settlements play an important role in cultural change and biodiversity determination. In the past, people have used many plant species to beautify their gardens by giving importance to flowering plants. Biodiversity can be determined by using the distribution of flowering plant species that have traditionally been preferred as species and in urban settlements. In this study, when the plants used in the settlement areas were investigated, 132 plant species belonging to 39 families were identified in a total of 200 sample areas. Five different residential areas were evaluated in the study. These can be listed as detached houses, traditional houses, villa houses, site, mass housing. It has been determined that non-natural species are used extensively in the research areas. It is observed that plant species natural plants and containing fruit are given priority in traditional gardens. It has been determined that unnatural species are used in other house types. For the continuity and protection of natural plant species, the garden order of traditional houses has been found more valuable.
\end{abstract}

\section{Kent Biyoçeşitliliği ve Kültürel Değişim Açısından Dış Mekan Süs Bitkilerinin Değerlendirilmesi: Niğde Kenti Örneği}

\section{Makale Bilgileri}

Geliş: 13.01.2021

Kabul: 13.09.2021

Online Yayınlanma: 15.12.2021

DOI: 10.29133/yyutbd.860641

\section{Anahtar Kelimeler}

Biyoçeşitlilik,

Ev Bahçeleri

Peyzaj,

Bitki Türleri,

Kent Bitkileri.

\begin{abstract}
Öz: Kırsal alanlarda kullanılan bitki türleri, kültürel değişim ve biyoçeşitliliğin belirlenmesinde önemli rol oynamaktadır. Geçmiş dönemlerde, insanlar çiçekli bitkilere önem vermiş ve bahçelerini güzelleştirmek için birçok bitki türleri kullanmışlardır. Biyoçeşitlilik, geleneksel olarak tercih edilmiş olan çiçekli bitki türlerinin dağılımı kullanılarak belirlenebilir. Bu çalışmada, yerleşim alanlarında kullanılan bitkiler incelendiğinde, 200 örnek alanda 39 familyaya ait 132 bitki türü belirlenmiştir. Çalışmada, beş faklı yerleşim alanı değerlendirilmiştir. Bunlar; Müstakil evler, Geleneksel evler, villa evler, site ve toplu konut olarak sıralanabilir. Araştırma alanında doğal olmayan türlerin yoğun olarak kullanıldığı tespit edilmiştir. Geleneksel evlerde öncelikli olarak meyve veren ve doğal türlerin kullanıldığı gözlemlenmiş̧tir. Diğer ev tiplerinde doğal olmayan türlerin kullanıldığı tespit edilmiştir. Doğal bitki türlerin sürekliliği ve korunması için geleneksel evlerin bahçe düzeni daha değerli bulunmuştur.
\end{abstract}

\section{Introduction}

For sustainable development, the landscape has recently gained importance and some measures are being developed at a national and global scale. CITES, Convention on Biodiversity (CBD), IUCN (The International Union for Conservation of Nature). It is aimed at the conservation of biological resources, as seen in the conventions on the protection and continuity of many plant species. Some 
aromatic and ornamental plants found in nature are used in agriculture, cosmetics, and medical fields. Our negative activities on natural species, recreation and tourism activities, food resources, forest resources, medicine, and energy requirements are among the factors affecting biodiversity. We are constantly harming biodiversity to meet our identified needs. Today, due to the increasing population, food, and unemployment, many agricultural areas are being destroyed and residential areas are being expanded with the transition from rural areas to urban life.

When the statistics for the year 2000 were evaluated, the total population was approximately 6 million, while 1200 people migrated from villages and towns. In parallel with the increase in population, the diminishing green and cultural areas are damaged. Plant species are in danger of extinction. Since urban ecology is not considered during the planning and planning phase of the city, it is being destroyed due to urbanization due to many environmental problems. The continuous expansion of urban settlement areas is constantly threatened by the habitats of biodiversity. The use of traditional plants will not only ensure the protection of biodiversity where the city develops but will also be beneficial for people living in these areas. Traditional houses, detached houses, villas, and sites with gardens, especially in developed and developing cities, are important places for the continuity of the species.

Urban and countryside home gardens contribute to the functioning and sustainability of the urban ecosystem, providing benefits such as pollination, a shelter for micro- and macro-fauna, and allowing geneflow between plant populations in and out of the garden (Surat and Yaman, 2017). Home gardens can be defined as 'land-use system involving deliberate management of multipurpose trees and shrubs in intimate association with annual and perennial agricultural crops and invariably livestock within the compounds of individual houses, the whole tree-crop animal unit being intensively managed by family labor'(Kumar and Nair, 2004).

Home gardens are important as a means of maintaining PGR (plant genetic resources) (Agelet et al., 2000; Sunwar et al., 2006) as potential hotspots of agricultural biodiversity (Kumar and Nair, 2004), as natural resources for alleviating poverty (Salako et al., 2014), and can help in reducing hunger and malnutrition in the impending world food crisis, climate change, and a large number of socioeconomic benefits (Cruz-Garcia and Struik, 2015; Galhena et al., 2013; Barbhuiya et al., 2016). Home gardens are places that are practiced in rural areas in many parts of the world and consist of layers of trees, shrubs, and herbs plants. Several studies integrate ecological data with socioeconomic aspects in ethnobotanical research, addressing the utilization of plants by traditional so $\neg$ cieties (Davoren et al., 2016; Palliwoda et al., 2017), people's plants' preferences (Kendal et al., 2012), or with landscape design (Petrík et al., 2019). People living in home gardens in rural areas grow cultural varieties along with native plant varieties. There are different life forms of these plant types (tree, shrub, herbaceous, etc.). Turkey due to its geographical location where there are many different plant species. In our country, many different types of ornamental plants grow naturally. However, the use of natural plants in the urban environment is limited (Richards et al., 1984; Cornelis and Hermy, 2004).

In Turkey, more recently, because longing for the green garden needed by the people is increasing day by day to homes and sites of interest. Due to the climatic characteristics that limit the diversity of plant species, many local ornamental plants and products are being given importance in cities. The importance given to ornamental plants has started to increase in vineyard houses and other house types which are also traditional in Niğde. Therefore, the main purpose of the research is to determine the diversity of plants used in traditional hoses and other house gardens and to develop recommendations to understand their importance in the preservation of food, income source, ornamental plant, and indigenous plant diversity. Since the plant species used are produced or cultivated in rural areas, indigenous species appear in the home gardens. This study will provide information about biodiversity due to plant species used in landscaping in Niğde. The plant species used in the settlement areas vary according to the type of house, the distance to the city center, and the type. In this context, it has been observed that the use of woody ornamental plants is emphasized. It is aimed to determine the relationship between the type of settlement areas and the diversity of plant species used.

\section{Materials and Methods}

The city of Niğde, chosen as the study area, is between the north latitudes $37^{\circ} 25^{\prime}-38^{\circ} 58^{\prime}$ and the longitudes of $33^{\circ} 10^{\prime}-35^{\circ} 25^{\prime}$ east. The surface area of the province is $7400 \mathrm{~km}^{2}\left(7365 \mathrm{~km}^{2}\right)$ and covers $4.87 \%$ of the territory of Central Anatolia (151 176) and $0.90 \%$ of the country's territory (814 
$578 \mathrm{~km}^{2}$ ) (Sever and Kopar, 2019). The research area is about 5.700 hectares (TÜIK, 2019). Niğde, 2019 Turkey is a town with 352727 inhabitants according to data from the statistical office. The population of the city of Niğde, on the other hand, shows rapid development due to the migration reasons it receives from villages and different places. Due to migration from villages and different places, the city develops very rapidly in terms of spatial development. According to Davis et al. (1988), the boundaries of Nigde are located in the squares B4, B5, C5. Niğde Province has an altitude of $1300 \mathrm{~m}$ and annual rainfall is $340.1 \mathrm{~mm}$. The average annual temperature is $-0.40^{\circ} \mathrm{C}$ in January and $22.40{ }^{\circ} \mathrm{C}$ in August. The Terrestrial climate is dominant.

As the research area, the buildings where the ornamental plants are used more in the city of Niğde were selected and classified as Niğde's traditional houses, villas, detached houses, estates, and mass housing areas. Some of the provincial land located in the Central Kiz1lirmak Section of the Central Anatolia Region is located in the Adana Section of the Mediterranean Region (Figure 1).

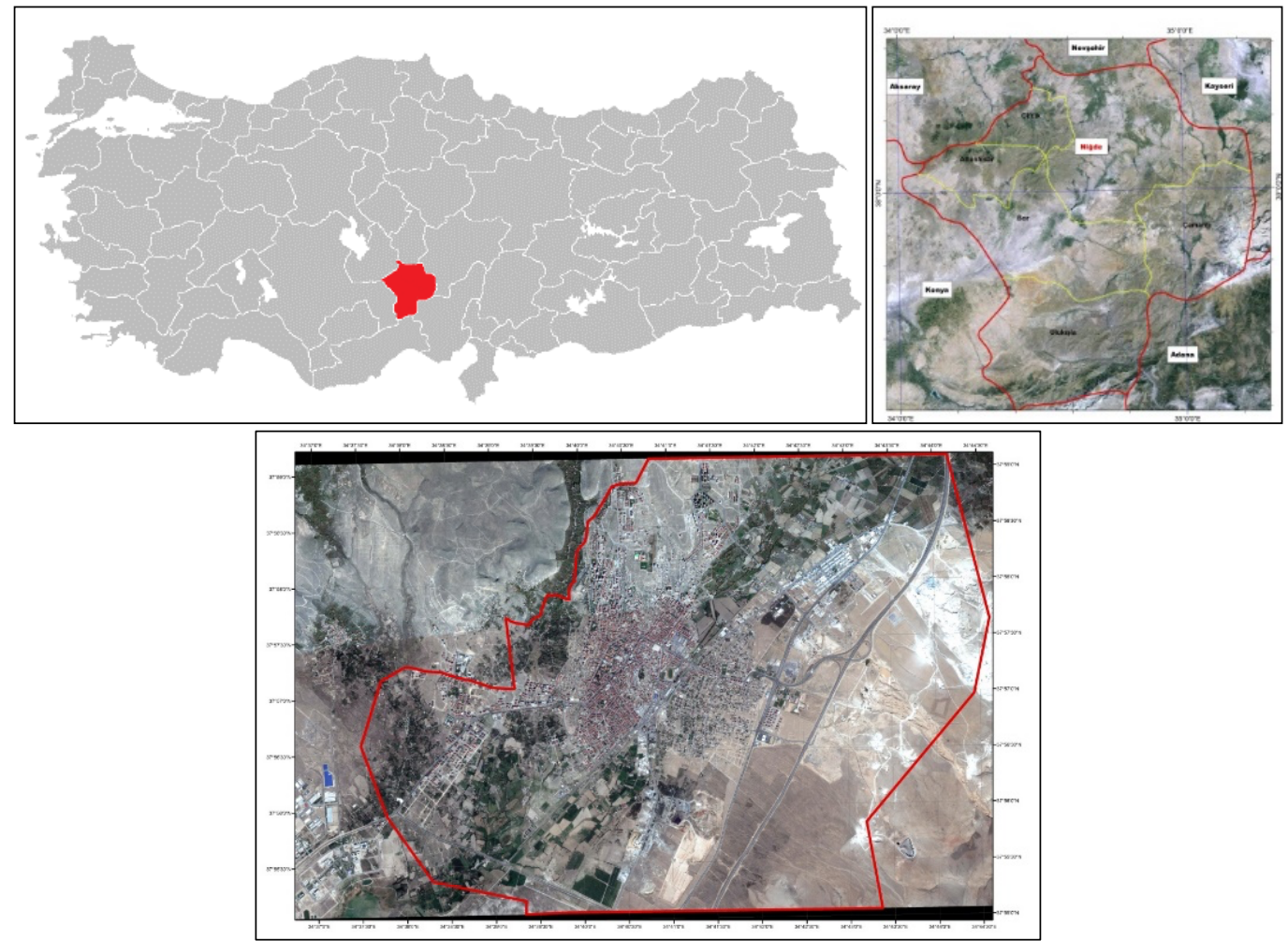

Figure 1. The site of the experiment, the Niğde province.

In the houses selected as research areas in Niğde city (detached, traditional, villa, site, mass housing), the results of the research were evaluated in two stages as used plants (biodiversity) and landscape areas. In the study area, 132 plant species belonging to 39 families were recorded in 200 sample areas.

The plant species in the study coming from the five different groups were evaluated based on the characteristics and classification listed in Table 1. The resulting data file had 24 qualitative variables for 132 entities from five groups. The entities and their group and entity codes are given in Table 2.

The data then were analyzed by using two multivariable statistical analyses, principal coordinate (PCoA) and clustering analyses. First, PCoA was carried out for quantitative data files using SAS (SAS, 1990). The same data file was subjected to a clustering analysis performed by the unweighted pair-group method using the arithmetic average (UPGMA) method with NTSYS-PC Program.

\subsection{Data analysis}

We have been calculated for each of them the mean diversity and occurrence values in order to characterize the structural features of each residential setting. 
Different species exist in plant communities with high heterogeneity and are numerous. May (1975) concluded that Berger-Parker index was one of the most satisfactory diversity measures available. Shannon - Weiner index $\left(\mathrm{H}_{1}=-\sum\right.$ piLn pi), where $\mathrm{pi}=\mathrm{ni} / \mathrm{N}$ (ni is the number of individuals of species, $\mathrm{i}$ and $\mathrm{N}$ is the total number of individuals), was used to determine the species diversity in the research area.

Margalef measure $\left(\mathrm{DM}=\left(\mathrm{S} \_1\right) / \mathrm{Ln}(\mathrm{N})\right)$ and the dominance indices of Berger-Parker index $(\mathrm{d}=$ Nmax/NT), (Nmax is total dominant species in a habitat type and NT is the proportion of the total species), was used to describe species diversity indexes and plant community characteristics. Pielou's evenness index $\left(\mathrm{J}_{1}=\mathrm{H}_{1} / \log \mathrm{S}\right)$, where $\mathrm{S}$ is the number of species) was used to measure the structural composition of the communities (Magurran, 1988, Acar et al., 2007).

Assessment of plant life type characteristics was performed in Microsoft Excel 2016.

\section{Discussion and Conclusion}

The results were evaluated in two parts in this study: Floral and landscape.

\subsection{Floral Assessment}

The study area, which consists of 200 gardens, consists of $14 \%$ traditional, $29 \%$ detached, $16 \%$ villa, 32\% site, 9.5\% mass housing (Figure 2).
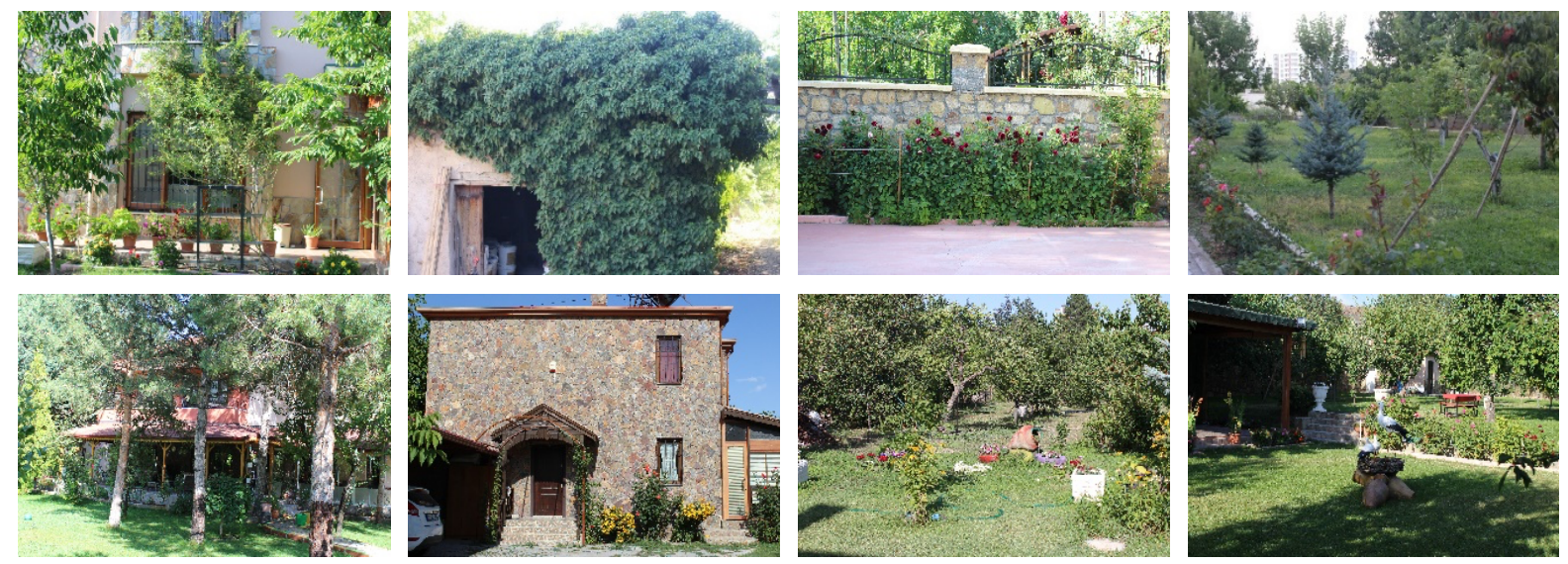

Figure 2. Nigde villas and detached houses.

As the plant species used in the mass housing were the same, a smaller number was evaluated. As most traditional houses are empty, there is no diversity in the gardens. There are several fruit trees from the past. In order to determine the plant density used in these selected gardens, Shannon-Wiener, Margalef, and Berger-Parker analysis was applied (Figure 3). According to the results, intensive use of trees is seen. 

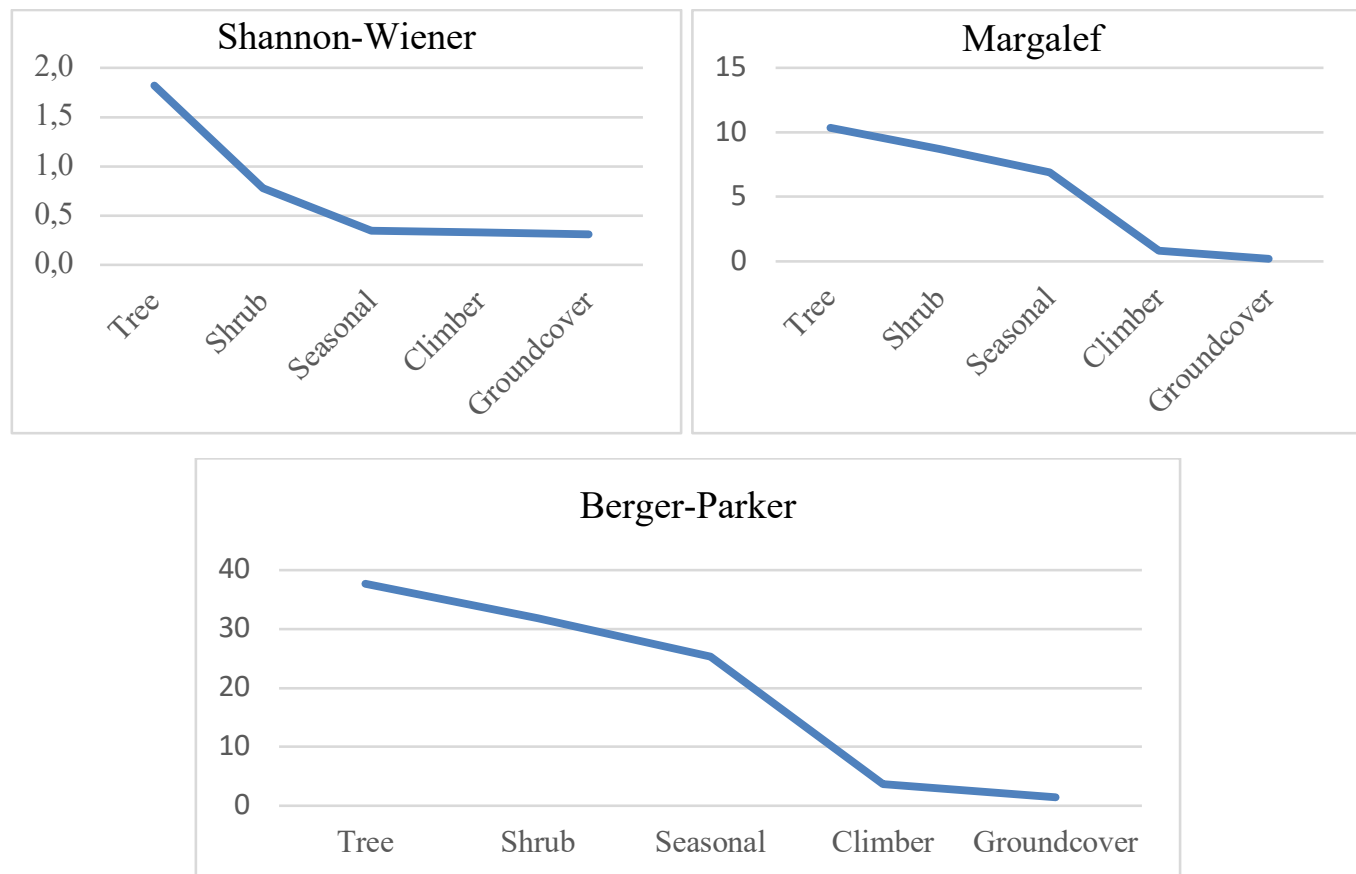

Figure 3. Use of Plant Species in Settlement Types in the Study Area.

\subsection{Landscape Assessment}

The distribution, richness, and diversity of plant species in Niğde City were evaluated according to houses, and their usage areas in landscaping were determined. It is thought whether the plant species used in the urban environment reflect the cultural change, and studies are needed to determine the effectiveness of socio-cultural structure in the distribution of plant species.

It is seen that traditional structures are not preserved and conservation policies are inadequate in urban areas. Identification of cultural origin buildings, protection of urban landscapes, and historical sites will contribute to the protection of biodiversity. However, this requires the development of additional research to clarify the contribution of rural landscapes to the environment, economy, and society, even though their importance has been indicated in previous research (Antrop, 2005; Agnoletti, 2014).

Landscapes are dynamic and change is one of their properties. Humans have always adapted their environment to better fit the changing societal needs and thus reshaped the landscape. All the important driving forces are related to the population growth and the lifestyle becoming increasingly more urban and more mobile (Antrop, 2005). The loss or decrease of cultural and natural areas in the 21 st century is increasing today and is now worrying about people. Sustainability cannot be said to be very good when compared to the past with the conservation of biodiversity and landscape as well as cultural areas. Reproduction and sustainability of existing biodiversity can be considered as an important criterion. In addition to the ancestral values in the landscape, ornamental plants are concrete examples. In the past, the landscape may not be restored, but valuable elements and areas can be studied about how to protect.

All of the plant materials are greatly important for urban landscapes and shaping green areas (Sukopp and Werner, 1983; Sukopp, 2004; Acar et al., 2007). Our aim is to determine the interaction between humans and plants where the urban landscape is. Accordingly, the different home styles and gardens that constitute the source of the research are the sources that will inform us in monitoring and identifying the biodiversity and cultural change of the urban landscape. It will shed light on later issues with the proposed results. In the traditional houses of Niğde, the gardens were built adjacent to the high walls because of the Greeks who lived before. Care was taken to ensure that the plants used in these houses were fruiting and flowering. Rather than choosing ecologically appropriate species in the gardens of villas, detached houses, housing estates, and public housing, emphasis was placed on the use of pleasing and cultured plants (Cupressocyparis leylandii, Cupressus macrocarpa, Dahlia hybrida, 
Matricaria chamomilla, Celosia argentea, Salvia splendes, Osteospermum ecklonis, Weigela floribunda, Picea orientalis, Picea pungens, Morus alba pendula).

The data from our study were subjected to multivariate analyses using principal coordinate analyses. The results of the PCoA for the 24 variables used in the analyses of outdoor ornamental plants of the different residential landscapes of Niğde are presented in Table 1. The characteristics and relevant classifications of the evaluation of outdoor ornamental plants used in the study. The second part of the table, list the correlation coefficient of the first five dimensions (D) for the variables. The first five dimensions explained $23,11,8,7$, and $6 \%$ of the total variation tabulating a cumulative value of $54 \%$. The variables which had the greatest correlation coefficient with D1 were V01, V12, V16, V19, and V20. V02, V13, and V14 were the most important for D2 while V07, V09, and V15 were the most important for D3. Overall, each variable had an important contribution to the calculation of at least one dimension.

Table 1. The characteristics and relevant classifications of the evaluation of outdoor ornamental plants of the different residential landscapes of Niğde

\begin{tabular}{llrrrrrr}
\hline Plant Form & Classification & Code & D1 & D2 & D3 & D4 & D5 \\
\hline Plant life type & Tree & V01 & 0.33 & -0.32 & 0.03 & -0.02 & 0.05 \\
& Shrub & V02 & 0.05 & 0.55 & 0.00 & -0.03 & -0.09 \\
& Seasonal & V03 & -0.20 & -0.14 & 0.22 & -0.34 & 0.38 \\
& Perennial & V04 & 0.19 & -0.01 & -0.19 & 0.34 & -0.39 \\
& Ground cover & V05 & -0.12 & 0.21 & -0.01 & -0.12 & 0.02 \\
Aesthetic and visual & Climber & V06 & -0.06 & 0.13 & 0.04 & 0.51 & 0.10 \\
& Flowers with effective & V07 & -0.13 & 0.14 & 0.46 & 0.12 & 0.19 \\
& Fruit with effective & V08 & 0.19 & -0.04 & 0.25 & -0.14 & -0.43 \\
& Effective with leaves & V09 & 0.12 & -0.01 & -0.41 & -0.23 & -0.01 \\
Functional features & Effective with stems & V10 & 0.22 & -0.10 & -0.23 & 0.00 & 0.29 \\
& Calligraphic effect & V11 & 0.20 & -0.20 & -0.18 & -0.04 & 0.09 \\
& Habitat & V12 & 0.33 & 0.12 & 0.01 & -0.07 & -0.06 \\
& Texture & V13 & 0.29 & 0.28 & 0.03 & -0.15 & -0.03 \\
& Hedge & V14 & 0.02 & 0.28 & 0.06 & -0.18 & -0.16 \\
& Fruit & V15 & 0.13 & -0.19 & 0.44 & -0.07 & -0.29 \\
Bigenvalue & Border & V16 & 0.25 & 0.33 & -0.03 & 0.02 & 0.17 \\
Correlation coefficient & Climber & V17 & -0.12 & 0.04 & 0.03 & 0.49 & 0.04 \\
\hline & Direction & V18 & 0.22 & 0.18 & 0.26 & -0.07 & 0.21 \\
Socio-economic characteristics & Regional integrity & V19 & 0.25 & 0.04 & -0.01 & 0.03 & 0.11 \\
& Ocreening & V20 & 0.29 & 0.12 & 0.00 & 0.19 & 0.13 \\
& Emphasis & V21 & 0.25 & -0.25 & 0.16 & 0.20 & 0.08 \\
& Shade & V22 & 0.26 & -0.06 & 0.05 & 0.01 & 0.17 \\
& Natural & 0.15 & -0.09 & 0.29 & 0.03 & -0.02 \\
& & & 0.06 & 0.06 & 0.03 & 0.07 & 0.35 \\
& & & 0.23 & 0.11 & 0.08 & 0.07 & 0.06 \\
\hline
\end{tabular}

D1. Detached houses, D2. Traditional houses, D3. Villa houses, D4. Site, D5. Mass housing.

As a result in Table 1; when evaluated in terms of plant life type, it was observed that shrub group was preferred in traditional houses and seasonal plants were preferred in villa type. In terms of aesthetic and visual aspects, respectively, villas were classified according to effectiveness with flowers, detached houses were classified according to habitat status, traditional houses were classified according to texture. In the case of functional features, it is determined that the villas are preferred plants effective with fruit, traditional houses preferred plants as border plants. 
The resulting data file had 24 qualitative variables for 132 entities from five groups. The entities and their group and entity codes are given in Table 2.

Table 2. The list of plant species, their group, and analyses code used in the evaluation of outdoor ornamental plants of the different residential landscapes of Niğde

\begin{tabular}{|c|c|c|c|c|c|c|}
\hline $\begin{array}{l}\text { Residential } \\
\text { landscapes type }\end{array}$ & Species & Family & $\begin{array}{l}\text { Plant life } \\
\text { type }\end{array}$ & Origin & $\begin{array}{l}\text { Group } \\
\text { code }\end{array}$ & Code \\
\hline \multirow[t]{14}{*}{ Detached } & Abelia grandiflora & Caprifoliaceae & Shrub & China & M60 & S01 \\
\hline & Amygdalus communis & Rosaceae & Fruit tree & Asia & M108 & S10 \\
\hline & Aster sp. & Compositae & Perennial & America & M15 & S13 \\
\hline & Buddleia davidii & Buddlejaceae & Shrub & China & M50 & S18 \\
\hline & Cotoneaster franchetii & Rosaceae & Shrub & China & M45 & S26 \\
\hline & Cotoneaster microphylla & Rosaceae & Shrub & Asia, Himalayan & M46 & S28 \\
\hline & $\begin{array}{l}\text { Cupressocyparis } \\
\text { leylandii }\end{array}$ & Cupressaceae & Tree & America & M101 & $\mathrm{S} 30$ \\
\hline & $\begin{array}{l}\text { Cupressus sempervirens } \\
\text { var. pyramidalis }\end{array}$ & Cupressaceae & Tree & $\begin{array}{l}\text { South Europe, Turkey, } \\
\text { Iran }\end{array}$ & M95 & S34 \\
\hline & Gaura lindheimeri & Onagraceae & Shrub & Texas & M61 & S51 \\
\hline & Mahonia aquifolium & Berberidaceae & Shrub & North California & M57 & S76 \\
\hline & Pyracantha coccinea & Rosaceae & Shrub & Asia, Italy, Turkey & M63 & S107 \\
\hline & Robinia pseudoacacia & Fabaceae & Tree & USA & M104 & S111 \\
\hline & Thuja orientalis & Cupressaceae & Shrub & China, Turkestan & M59 & S126 \\
\hline & Wisteria sinensis & Fabaceae & Climbing & China & M38 & S137 \\
\hline \multirow[t]{25}{*}{ Traditional } & Abies bornmülleriana & Pinaceae & Tree & Turkey & G89 & S02 \\
\hline & Abies sp. & Pinaceae & Tree & Turkey & G70 & S04 \\
\hline & Ailanthus altissima & Simaroubaceae & Tree & China & G84 & S08 \\
\hline & Antirrhinum majus & Scrophulariaceae & Perennial & Mediterranean & G29 & S11 \\
\hline & Begonia semperflorens & Begoniaceae & Perennial & Brazil & G04 & S14 \\
\hline & Campsis radicans & Bignoniaceae & Climbing & America & G35 & S20 \\
\hline & Celosia argentea & Amaranthaceae & Annual & Africa & G19 & S22 \\
\hline & Cornus mas & Cornaceae & Shrub & Europe & G45 & S24 \\
\hline & Cupressus macrocarpa & Cupressaceae & Tree & California, America & G88 & S32 \\
\hline & Cynodon dactylon & Poaceae & Perennial & Africa & G32 & S36 \\
\hline & Dahlia sp. & Asteraceae & Perennial & Mexico & G17 & S38 \\
\hline & Dianthus barbatus & Caryophyllaceae & Perennial & Europe & G02 & S40 \\
\hline & Eleagnus angustifolia & Elaeagnaceae & Fruit tree & Europe, Asia, Turkey & G85 & S42 \\
\hline & Euryops pectinatus & Asteraceae & Perennial & Africa & G10 & S45 \\
\hline & Festuca glauca & Poaceae & Perennial & Turkey & G33 & S47 \\
\hline & Freesia reflecta & Iridaceae & Perennial & Africa & G01 & S50 \\
\hline & Gladiolus sp. & Iridaceae & Perennial & Asia & G12 & S53 \\
\hline & Gomphrena globosa & Amaranthaceae & Annual & Panama & G31 & S54 \\
\hline & Hibiscus syriacus & Malvaceae & Tree & Pakistan & G42 & S56 \\
\hline & Impatiens walleriana & Balsaminaceae & Perennial & Asia, America, Africa & $\mathrm{G} 28$ & S59 \\
\hline & Jasminum fruticans & Oleaceae & Shrub & Mediterranean & G55 & S61 \\
\hline & Juglans regia & Junglandaceae & Tree & Iran & G75 & S63 \\
\hline & Kerria japonica & Rosaceae & Shrub & China & G63 & S68 \\
\hline & Lagerstroemia indica & Lythraceae & Shrub & China & M47 & S69 \\
\hline & Lavandula officinalis & Lamiaceae & Shrub & Mediterranean, Turkey & G61 & S70 \\
\hline
\end{tabular}


Table 2. The list of plant species, their group and analyses code used in the evaluation of outdoor ornamental plants of the different residential landscapes of Niğde (continue)

\begin{tabular}{|c|c|c|c|c|c|c|}
\hline $\begin{array}{l}\text { Residential } \\
\text { landscapes type }\end{array}$ & Species & Family & $\begin{array}{l}\text { Plant life } \\
\text { type }\end{array}$ & Origin & $\begin{array}{l}\text { Group } \\
\text { code }\end{array}$ & Code \\
\hline \multirow[t]{19}{*}{ Traditional } & Lonicera involucrata & Caprifoliaceae & Shrub & America & G37 & S74 \\
\hline & Matricaria chamomilla & Asteraceae & Annual & Europe & G30 & S78 \\
\hline & Morus alba & Moraceae & Fruit tree & China, Japan & G73 & S80 \\
\hline & Narcissus sp. & Amaryllidaceae & Perennial & Mediterranean & G26 & S82 \\
\hline & Osteospermum ecklonis & Asteraceae & Annual & Africa & G34 & S84 \\
\hline & Pelargonium radula & Geraniaceae & Shrub & Africa & G59 & S86 \\
\hline & Picea orientalis & Pinaceae & Tree & Turkey, Caucasian & G71 & S90 \\
\hline & Petunia sp. & Solanaceae & Annual & America & G16 & S88 \\
\hline & Portulaca grandiflora & Portulacaceae & Annual & Argentina & G06 & S97 \\
\hline & Prunus armenica & Rosaceae & Fruit tree & Turkey, Europe, Iran & G80 & S99 \\
\hline & Prunus domestica & Rosaceae & Fruit tree & Caucasian & G79 & S105 \\
\hline & Rhus sp. & Anacardiaceae & Shrub & Anatolia, China & G43 & S109 \\
\hline & Rosa rampicanti & Rosaceae & $\begin{array}{l}\text { shrubs, } \\
\text { climbing }\end{array}$ & Asia & G38 & S113 \\
\hline & Rosmarinus officinalis & Labiatae & Shrub & $\begin{array}{l}\text { North Africa, } \\
\text { Mediterranean Countries, } \\
\text { Turkey }\end{array}$ & G50 & S115 \\
\hline & Rudbeckia hirta & Asteraceae & $\begin{array}{l}\text { Annual, } \\
\text { biennial }\end{array}$ & America & G07 & S117 \\
\hline & Salvia splendes & Lamiaceae & Perennial & Brazil & $\mathrm{G} 27$ & S119 \\
\hline & Tagetes erecta & Asteraceae & $\begin{array}{l}\text { annual or } \\
\text { perennial }\end{array}$ & Mexico & G08 & S123 \\
\hline & Tilia tomentosa & Malvaceae & Tree & Earth Europe, Turkey & G68 & S128 \\
\hline & Vitis vinifera & Vitaceae & Climbing & Mediterranean & G36 & S135 \\
\hline \multirow[t]{22}{*}{ Villa } & Acer campestre & Aceraceae & Tree & Europe, Asia & V137 & S05 \\
\hline & Acer negundo & Aceraceae & Tree & America, Canada & V122 & S06 \\
\hline & Aesculus hippocastanum & Sapindaceae & Fruit tree & $\begin{array}{l}\text { Balkan, Turkey, } \\
\text { Peninsula }\end{array}$ & V124 & S07 \\
\hline & Alcea rosea & Malvaceae & Shrub & Asia & V78 & S09 \\
\hline & Asparagus officinalis & Asparagaceae & Perennial & Europe & V34 & $\mathrm{S} 12$ \\
\hline & Betula alba & Betulaceae & Tree & Europe, Asia, Turkey & V130 & $\mathrm{S} 16$ \\
\hline & Bougainvillea glabra & Nyctaginaceae & Climbing & Brazil & V43 & S17 \\
\hline & Buxus sempervirens & Buxaceae & Shrub & Europe & V127 & S19 \\
\hline & Corylus avellana & Betulaceae & Fruit tree & Europe, Turkey & V112 & $\mathrm{S} 25$ \\
\hline & Crataegus monogyna & Rosaceae & Fruit tree & Europe, Turkey & V128 & $\mathrm{S} 29$ \\
\hline & Cydonia oblonga & Rosaceae & Fruit tree & Turkey, Iran & V109 & S35 \\
\hline & $\begin{array}{l}\text { Dianthus } \\
\text { gratianopolitanus }\end{array}$ & Caryophyllaceae & Perennial & Europe, Asia & V22 & S41 \\
\hline & Felicia amelloides & Asteraceae & Shrub & North Africa & V89 & $\mathrm{S} 46$ \\
\hline & Fraxinus exelsior & Oleaceae & Tree & Europe, Turkey & V123 & $\mathrm{S} 49$ \\
\hline & Gazania rigens & Asteraceae & Perennial & Africa & V26 & S52 \\
\hline & Hedera helix & Araliaceae & Climbing & Europe & V47 & S55 \\
\hline & Hyacinthus sp. & Liliaceae & Perennial & Asia & V28 & S57 \\
\hline & Ilex aquifolium & Aquifoliaceae & Shrub & Europe, Africa, China & V85 & S58 \\
\hline & Ixora coccinea & Rubiaceae & Shrub & Asia & V97 & S60 \\
\hline & Jasminum officinale & Oleaceae & Shrub & India & V94 & S62 \\
\hline & Kalanchoe & Crassulaceae & Perennial & Madagascar & V10 & S67 \\
\hline & Leucanthemum vulgare & Asteraceae & Perennial & Europe & V07 & S71 \\
\hline
\end{tabular}


Table 2. The list of plant species, their group and analyses code used in the evaluation of outdoor ornamental plants of the different residential landscapes of Niğde (continue)

\begin{tabular}{|c|c|c|c|c|c|c|}
\hline $\begin{array}{l}\text { Residential } \\
\text { landscapes type }\end{array}$ & Species & Family & $\begin{array}{l}\text { Plant life } \\
\text { type }\end{array}$ & Origin & $\begin{array}{l}\text { Group } \\
\text { code }\end{array}$ & Code \\
\hline \multirow[t]{33}{*}{ Villa } & Ligustrum vulgare & Oleaceae & Shrub & Japan & V70 & S72 \\
\hline & Lilium sp. & Liliaceae & Perennial & China, Japan & V27 & S73 \\
\hline & Lycium barbarum & Solanaceae & Tree & Himalayan & V96 & S75 \\
\hline & Morus alba pendula & Moraceae & Fruit tree & China & V107 & S81 \\
\hline & Ocimum basilicum & Lamiaceae & Annual & Asia & V23 & S83 \\
\hline & Pelargonium peltatum & Geraniaceae & Shrub & Africa & V92 & $\mathrm{S} 85$ \\
\hline & Pelargonium zonale & Geraniaceae & Shrub & Africa & V90 & S87 \\
\hline & Philadelphus coronarius & Hydrangeaceae & Shrub & America & V60 & S89 \\
\hline & Pinus pinea & Pinaceae & Tree & $\begin{array}{l}\text { Mediterranean, Turkey, } \\
\text { Portugal, Spain }\end{array}$ & V143 & S92 \\
\hline & Pittosporum tobira & Pittossporaceae & Shrub & Mediterranean & V81 & S93 \\
\hline & Pittosporum variegata & Pittossporaceae & Shrub & China & V80 & S94 \\
\hline & Platanus orientalis & Platanaceae & Tree & Europe, Asia, Turkey & V136 & S95 \\
\hline & Populus alba & Salicaceae & Tree & Europe, Asia, Turkey & V133 & S96 \\
\hline & Primula sp. & Primulaceae & Perennial & China & V25 & S98 \\
\hline & Prunus avium & Rosaceae & Fruit tree & Europe, Africa, Turkey & V115 & S 100 \\
\hline & Prunus ceracifera & Rosaceae & Tree & Europe, Anatolia & V118 & S101 \\
\hline & $\begin{array}{l}\text { Prunus cerasifera } \\
\text { pissardii }\end{array}$ & Prunoideae & Tree & Europe, Asia & V131 & $\mathrm{S} 102$ \\
\hline & Prunus cerasus & Rosaceae & Fruit tree & Caucasian Sea, Anatolia & V119 & S103 \\
\hline & Prunus cerrulata & Prunoideae & Tree & Japan, Korea, China & V132 & S104 \\
\hline & Prunus persica & Rosaceae & Fruit tree & China & V116 & S106 \\
\hline & Robinia neomexicana & Fabaceae & Tree & Mexico & V139 & S 110 \\
\hline & Rubus canescens & Rosaceae & Shrub & Europe, Turkey & V77 & S116 \\
\hline & Salix babylonica & Salicaceae & Perennial & Çin & V145 & S118 \\
\hline & Saponaria officinalis & Caryophyllaceae & Perennial & Europe & V15 & $\mathrm{S} 120$ \\
\hline & Spirae vanhouttei & Rosaceae & Shrub & Hybrid & V68 & S121 \\
\hline & Tamarix tetrandra & Tamaricaceae & Shrub & America & V138 & $\mathrm{S} 124$ \\
\hline & Teucrium chamaedrys & Lamiaceae & Shrub & Mediterranean & V35 & $\mathrm{S} 125$ \\
\hline & Thymus sp. & Lamiaceae & Perennial & Europe, Asia & V24 & S127 \\
\hline & Ulmus glabra & Ulmacea & Tree & Europe, Caucasian & V125 & S129 \\
\hline & Vibirnum opulus & Caprifoliaceae & Shrub & $\begin{array}{l}\text { North Asia, Africa, } \\
\text { Europe, Turkey }\end{array}$ & V88 & $\mathrm{S} 130$ \\
\hline & Vinca major & Apocynaceae & $\begin{array}{l}\text { Ground } \\
\text { cover }\end{array}$ & Europe & V12 & S132 \\
\hline & Viola tricolor & Violaceae & Annual & Europe & V13 & S134 \\
\hline & Weigela floribunda & Caprifoliaceae & Shrub & Asia & V79 & S136 \\
\hline \multirow[t]{2}{*}{ Sites } & Mirabilis jalapa & Nyctaginaceae & Perennial & America & $\mathrm{S} 02$ & S79 \\
\hline & Viburnum tinus & Caprifoliaceae & Shrub & Mediterranean & $\mathrm{S} 20$ & $\mathrm{~S} 131$ \\
\hline \multirow[t]{7}{*}{ Mass housing } & Abies nordmanniana & Pinaceae & Tree & Caucasian, Anatolia & TK42 & S03 \\
\hline & Berberis thunbergii & Berberidaceae & Shrub & Japan & TK14 & S15 \\
\hline & Cedrus libani & Pinaceae & Tree & Turkey, Lebanon & TK34 & $\mathrm{S} 21$ \\
\hline & Cotoneaster horizontalis & Malaceae & Shrub & China & TK04 & S27 \\
\hline & Cupressus arizonica & Cupressaceae & Tree & America & TK46 & $\mathrm{S} 31$ \\
\hline & Cupressus pyramidalis & Cupressaceae & Tree & China & TK50 & $\mathrm{S} 33$ \\
\hline & Deutzia longifolia & Hydrangeaceae & Shrub & Asia & $\mathrm{S} 13$ & $\mathrm{~S} 39$ \\
\hline
\end{tabular}


Table 2. The list of plant species, their group and analyses code used in the evaluation of outdoor ornamental plants of the different residential landscapes of Niğde (continue)

\begin{tabular}{|c|c|c|c|c|c|c|}
\hline $\begin{array}{l}\text { Residential } \\
\text { landscapes type }\end{array}$ & Species & Family & $\begin{array}{l}\text { Plant life } \\
\text { type }\end{array}$ & Origin & $\begin{array}{l}\text { Group } \\
\text { code }\end{array}$ & Code \\
\hline \multirow[t]{10}{*}{ Mass housing } & Euonymus japonica & Celastraceae & Shrub & Japan & TK13 & S43 \\
\hline & Forsythia $\times$ intermedia & Oleaceae & Shrub & Asia & TK16 & $\mathrm{S} 48$ \\
\hline & Juniperus chinensis & & Fruit tree & Iran & TK25 & S64 \\
\hline & Juniperus horizontalis & Cupressaceae & Shrub & America & TK09 & S66 \\
\hline & Malus sp. & Rosaceae & Fruit tree & Asia & TK38 & S77 \\
\hline & Picea pungens & Pinaceae & Tree & America, Colorado & TK37 & S91 \\
\hline & Rosa canina & Rosaceae & Shrub & Hybrid & TK22 & S112 \\
\hline & Rosa sp. & Rosaceae & Shrub & Hybrid & TK27 & S114 \\
\hline & Syringa vulgaris & Oleaceae & Shrub & Asia, Europe, Turkey & TK17 & S122 \\
\hline & Zinnia elegans & Asteraceae & Shrub & Mexico & TK01 & $\mathrm{S} 138$ \\
\hline
\end{tabular}

The three dimensional plot of species used in principle coordinate analyses conducted by 24 qualitative characteristics in the evaluation of outdoor ornamental plants of the different residential landscapes of Niğde is presented in Figure 4. As seen in Figure 4, the species were grouped in three clusters. The same patterns were clearly confirmed by clustering analysis (Figure 5). The statistical analyses supported three groups. The species in each group are also listed in Figure 4in the order of appearance on the figure.

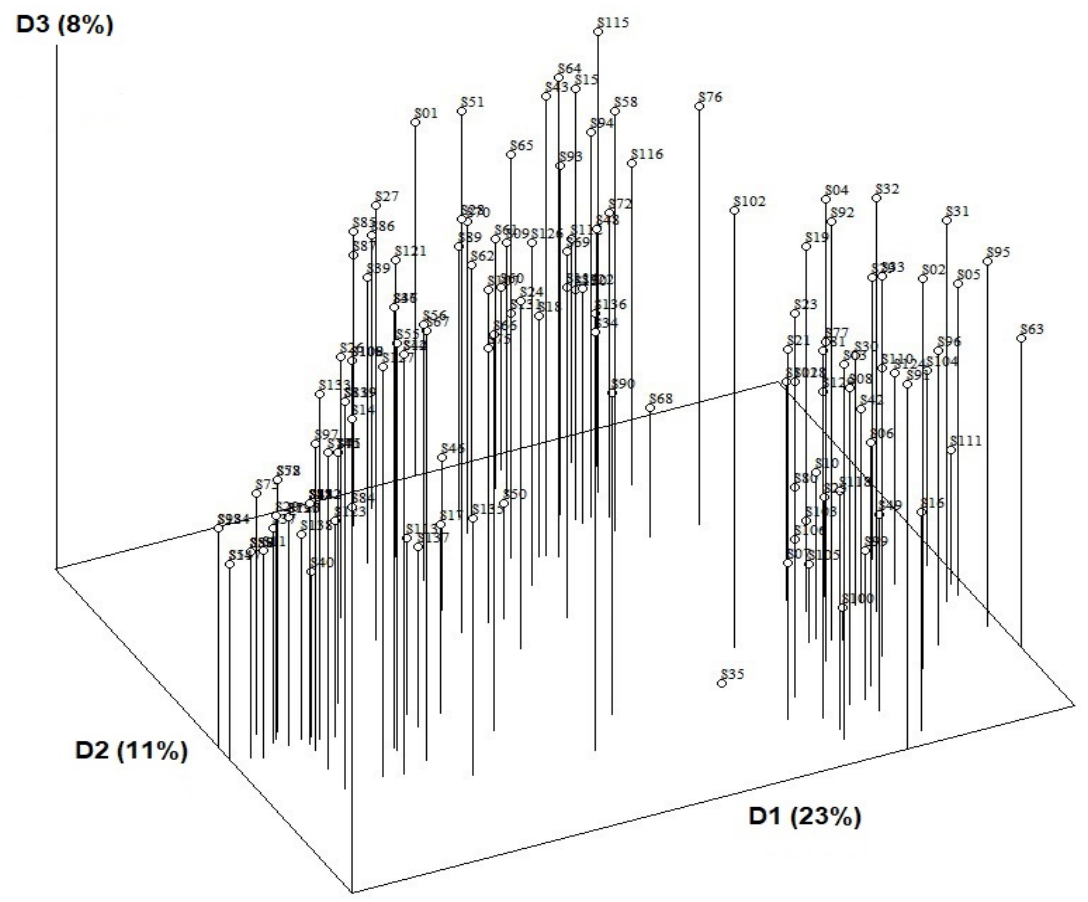

Figure 4. Three dimensional plot of species used in principle coordinate analyses conducted by 24 qualitative characteristics in the evaluation of outdoor ornamental plants of different residential landscape of Niğde.

Figure 4 clearly seen that cluster analysis, of the residential vegetation data is grouped into two main groups. The landscape of traditional residential areas and others.

Indeed, according to PCA and diversity results, vegetation structure and composition in traditional houses of the city of Niğde could be considered as a different and separate cluster of other houses. 
In addition to this, as it shown in Figure 5, plant species used in the Niğde settlement area and its surroundings could be distinguished by three major functional groups by using cluster analysis. This result corresponds with area observations, surveys, and species compositions.
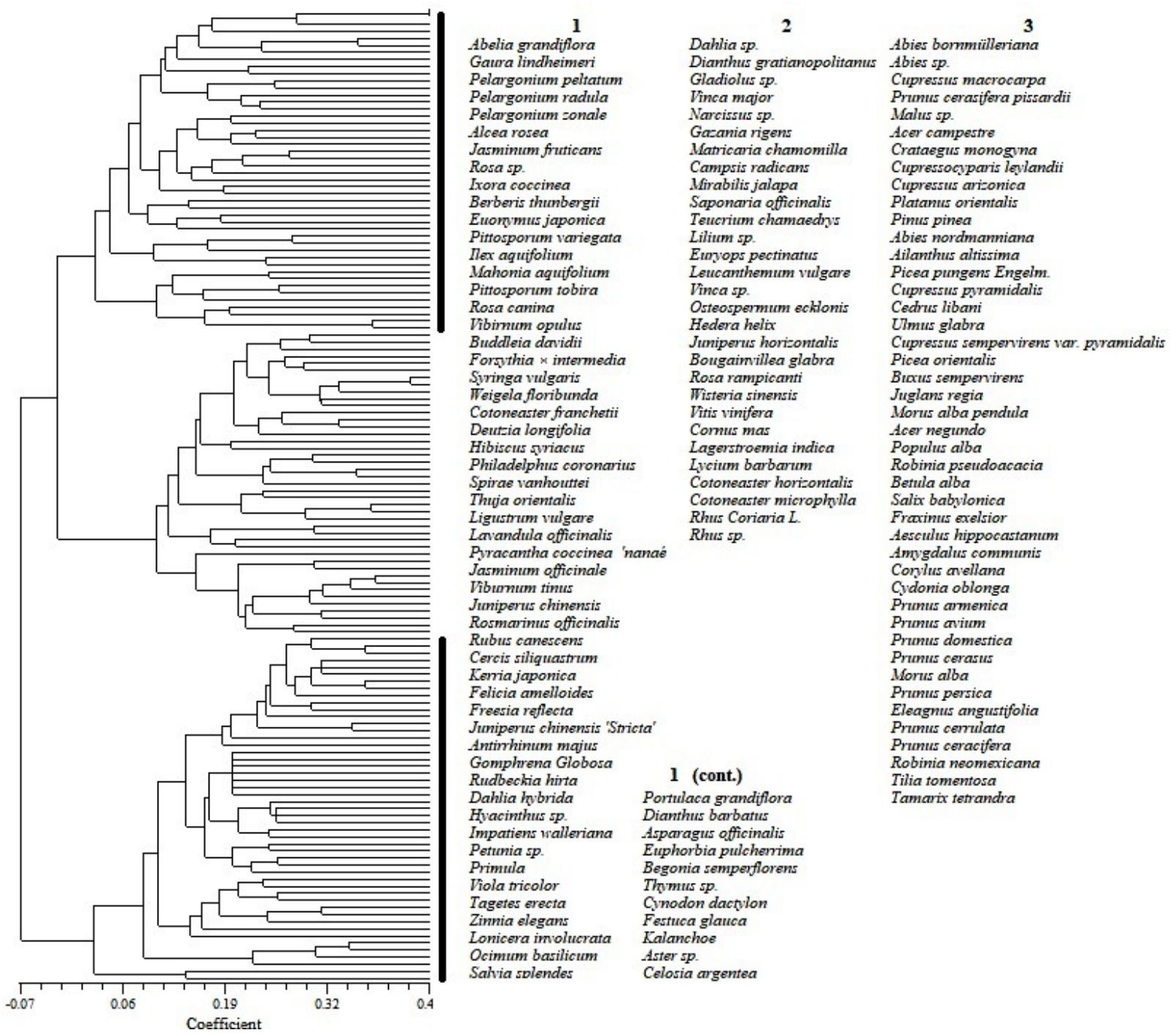

Figure 5. Dendrogram of species used in principle coordinate analyses conducted by 24 qualitative characteristics in the evaluation of outdoor ornamental plants of the different residential landscapes of Niğde.

Accordingly, it was obtained that Group 1 has shrub and groundcover, Group 2 has shrub, groundcover, and clutching stem, the other group included the trees species related with their compositions. This third group has many genera of horticultural fruit trees such as Prunus, Malus, Eleagnus, Juglans. The representatives of these genera were mostly used as hedge plants.

When the dendrogram was examined, some additional patterns were identified in the grouping of the plants used in Niğde. For example, it is seen that effective tree use with blossoms in Niğde is less and fruit trees use more with fruit. Leafy ornamental plants are being used for seasonal purposes. Perennial plants are frequently used in the grouping of the plants used in the Niğde landscape. Also, it was concluded that the fruit-bearing trees are frequently being used as hedge plants.

\section{Conclusion}

This study was conducted in Niğde province and it determined the usage, purposes, and methods of wild plants and natural plants in Detached, Traditional, Villa, Site, and Mass houses. Niğde has a 
wide potential for medicinal and aromatic plants studies. A total of 32 plant species belonging to 39 families were identified in the study area.

Different plant species were used in the landscape design of the houses in the residential areas of Niğde province. The study shows that local people prefer the plants mostly seasonal plants were preferred in villa type. In terms of aesthetic and visual aspects, respectively, villas were classified according to effectiveness with flowers, detached houses were classified according to habitat status, traditional houses were classified according to texture.

It has been observed that fruit-bearing tree and shrub species that are unique to the region are more preferred in different settlements in Niğde. The use of ornamental plants in villa-style home gardens is intense.

It is seen that effective tree use with blossoms in Niğde is less and fruit trees use more with fruit. Leafy ornamental plants are being used for seasonal purposes. Perennial plants are frequently used in the grouping of the plants used in the Niğde landscape. Also, it was concluded that the fruit-bearing trees are frequently being used as hedge plants.

Native plants of the region that will meet the landscape works to be done in urban spaces in terms of aesthetics and functionality should be preferred primarily. Exotic plants generally require more water, more nutrients, and more care to adapt to the ecological conditions, sometimes even these efforts do not give positive results. The same results were obtained in Nigde province.

It is necessary to benefit from native plants not only for aesthetic studies but also for functional landscape renewals such as biological repair works.

\section{References}

Acar, C., Acar, H., \& Eroğlu, E. (2007). Evaluation of Ornamental Plant Resources to Urban Biodiversity and Cultural Changing: A Case Study of Residatial Landscapes in Trabzon City (Turkey). Building and Enviroment, 42, 218-229.

Agelet, A., Angels, B. M., \& Valles, J. (2000). Homegardens and their role as a main source of medicinal plants in mountain regions of Catalonia (Iberian peninsula). Econ Bot 54, 295-309.

Agnoletti, M. (2014). Rural landscape, nature conservation and culture: Some notes on research trends and management approaches from a (southern) European perspective. Landscape and Urban Planning, 126, 66-73.

Antrop, M. (2005). Why landscapes of the past are important for the future. Landscape and Urban Planning, 70, 21-34.

Barbhuiya, A. R., Saho,o U. K., \& Upadhyaya, K. (2016). Plant Diversity in the Indigenous Home Gardens in the Eastern Himalayan Region of Mizoram, Northeast India. Economic Botany, $70(2), 115-131$.

Cornelis, J., \& Hermy, M. (2004). Biodiversity relationships in urban and suburban parks in Flanders. Landscape and Urban Planning, 69(4), 385-401.

Cruz Garcia, G. S., \& Struik, P. C. (2015). Spatial and seasonal diversity of wild food plants in home gardens of Northeast Thailand. Economic Botany, 69(2), 99113. https://doi.org/10.1007/s12231-015-9309-8

Davis, P. H., Mill, R. R., \& Tan, K. (1988) Flora of Turkey and the East Aegean Islands (Supplement). Vol.10.

Davoren. E., Siebert, S., Cilliers, S.S., \& du Toit, M. (2016). Influence of socioeconomic status on design of Botswana home gardens and associated plant diversity patterns in northern South Africa. Landscape and Ecological Engineering 12, 129-139. https://doi.org/10.1007/ s11355-0150279-x

Galhena, D. H., Freed, R., \& Maredia, K. M. (2013) Home gardens: a promising approach to enhance household food security and wellbeing. Agric Food Secur 2, 48-62

Kendal, D., Williams, K. J. H., \& Williams, N. S. G. (2012). Plant traits link people's plant preferences to the composition of their gardens. Landscape and Urban Planning 105, 34-42. https://doi. org/10.1016/j.landurbplan.2011.11.023

Kumar, B. M, \& Nair, P. K. R (2004). The enigma of tropical homegardens. Agroforestry Systems, 61, $135-152$. 
Magurran, A. E. (1988). Ecological Diversity and its Measurement. Princeton University Press, Princeton, 179.

May, R. M. (1975). Patterns of species abundance and diversity. In Ecology and evolution of communities, 81-120. Cambridge, MA: Harvard University Press.

Palliwoda, J., Kowarik, I., \& von der Lippe, M. (2017). Human-biodiversity interactions in urban parks: The species level matters. Landscape and Urban Planning, 157, 394-406. https:// doi.org/10.1016/j.landurbplan.2016.09.003

Petřík, P., Sádlo, J., Hejda, M., Štajerová, K., Pyšek, P., \& Pergl, J. (2019). Composition patterns of ornamental flora in the Czech Republic. NeoBiota, 52, 87-109. doi: 10.3897/neobiota.52.39260. http://neobiota.pensoft.net

Richards, N. A., Mallette, J. R., Simpson, R. J., \& Macie, E. A. (1984). Residential greenspace and vegetation in a mature city: Syracuse, New York. Urban Ecology, 8(1-2), 99-125.

Salako, V. K., Fandohan, B., Kassa, A. E., Assogbadjo, A. F. R., Idohou, R. C., Gbedomon, S., Chakeredza, M. E., Kaka, \& Dulloo, R. G., (2014). Home gardens: An assessment of their biodiversity and potential contribution to conservation of threatened species and crop wild relatives in Benin. Genetic Resources and Crop Evolution 61, 313-330.

SAS, (1990). SAS User's Guide: Statistics. Version 5 Edition, SAS Institute Inc., Cary.

Sever, R, \& Kopar, İ. (2019). Niğde İlinin Başlıca Coğrafi Özellikleri. www.nigdekulturturizm.gov.tr/Eklenti/9887, nigde-cografyadoc.doc?0 Accessed. 10.12.2020.

Sukopp, H., \& Werner, P. (1983). Urban environments and vegetation. In: Holzner W, Werger MJA, Ikusima I, editors. Man's impact on vegetation. The Hague: Dr. W. Junk Publishers; p. 247-60.

Sukopp., H. (2004). Human-caused impact on preserved vegetation. Landscape and Urban Planning, 68(4), 347-55.

Sunwar, S, Thornstrom, C, Subedi A, \& Bystrom, M. (2006). Home gardens in western Nepal: opportunities and challenges for on-farm management of agrobiodiversity. Biodiversity and Conservation 15, 4211-38

Surat, H., \& Yaman, Y.K. (2017). Evaluation of plant species in home gardens: A case study of Batumi city (Adjara). Turkish Journal of Forestry, 18(1), 11-20.

TÜIK, (2019). TÜIK, İstatistiklerle Türkiye, (www.tuik.gov.tr) 